\title{
Feminismo y Derecho Penal
}

\section{Feminism and Criminal Law}

\author{
Luis Hernán Acevedo Espínola ${ }^{1}$
}

\begin{abstract}
RESUMEN
En el presente trabajo se pretende abordar cómo el feminismo ha influido en el Derecho Penal chileno, observando en primer lugar el fenómeno político del feminismo, considerando la gran fuerza que este movimiento ha tenido en Chile, para luego, en segundo lugar, observar la influencia de este movimiento en el Derecho Penal chileno. En dicho contexto, se abordarán tres reformas al Derecho Penal sustantivo de este último tiempo: La Ley sobre Interrupción Voluntaria del Embarazo, Ley No21.030; la Ley sobre el Femicidio, Ley No20.480; y la Ley sobre Acoso Sexual en Espacios Públicos, Ley No21.153. Como se observará, la tesis central de este trabajo es que, si bien el feminismo ha influido en el Derecho Penal, ello no ha implicado establecer una asimetría inversa, sino que una igualdad de derechos en la legislación penal entre hombres y mujeres. Finalmente, terminaré el trabajo con algunas conclusiones.
\end{abstract}

Palabras Clave: Feminismo, Derecho Penal, Aborto, Femicidio y Acoso Sexual.

\begin{abstract}
In this work I pretend analyse how the feminism has influenced in the Chilean Criminal Law, looking in first place the political phenomenon of feminism, considering the great strength that this movement has had in Chile, and then, secondly, observing the influence of this movement in Chilean Criminal Law. In this context, three reforms to the substantive Criminal Law of this last time will be addressed: The Law on Voluntary Interruption of Pregnancy, Law No. 21.030; the Law on Femicide, Law No. 20,480; and the Law on Sexual Harassment in Public Spaces, Law No. 21,153. As will be seen, the central thesis of this paper is that, although feminism has influenced Criminal Law, this has not meant establishing an inverse asymmetry, but equality of rights in criminal legislation between men and women. Finally, I will finish this work with some conclusions.
\end{abstract}

Keywords: Feminism, Criminal Law, Interruption of Pregnancy, Femicide and Sexual Harassment.

\section{Introducción}

Según Carlos Cruz-Coke Ossa, se entiende por fuerzas políticas "todas aquellas que de alguna manera influyen en la vida estatal y que presionan sobre ella, y de la cual dependen el nacimiento, la existencia o la muerte de las instituciones politicas estatales" ${ }^{2}$. Entre dichas fuerzas políticas encontramos a los partidos políticos, los grupos de presión, la opinión pública y, excepcionalmente, las Fuerzas Armadas.

\footnotetext{
Abogado UDD, Magíster en Derecho Penal y Procesal Penal UDP, Profesor Introducción al Derecho USACH y Compliance UNAB. Correo electrónico: luishacevedoe@gmail.com

2 CRUZ-COKE OSSA, Carlos, “Instituciones Politicas y Derecho Constitucional”, Ediciones Universidad Finis Terrae, Noviembre de 2009 , p. 241.
} 
El caso del feminismo es tanto un caso de grupo de presión, como un caso de opinión pública como fuerza política. Por grupo de presión se entiende a aquel conglomerado social que se politiza buscando satisfacer sus propias necesidades ${ }^{3}$, como son los gremios o los sindicatos, entre otros. Estos grupos de presión están autorizados por la Constitución Política de la República (CPR) ya que se trata del ejercicio de un derecho fundamental, cual es el derecho de libre asociación, reconocido en el numeral 15 del artículo 19 de la Carta Magna ${ }^{4}$. Asimismo, éstos constituyen lo que el constituyente denomina "cuerpos intermedios", a los cuales se les reconoce la adecuada autonomía para el cumplimiento de sus fines, conforme lo dispone el artículo 1 de la CPR 5 . Otro punto, claro está, será en cómo la legislación los regula para efectos del ejercicio de su fuerza política como tal, lo cual se encuentra principalmente regulado en la Ley del Lobby, Ley No20.730.

Por su parte, la opinión pública como fuerza política se manifiesta como la opinión mayoritaria en un espacio y tiempo determinado, sobre un punto en específico, y que responde a un sentimiento colectivo ${ }^{6}$. Esta fuerza política se caracteriza por ser una fuerza social y difusa, al mismo tiempo que está también autorizado por la CPR ya que, al igual que en el caso anterior, se trata del ejercicio de un derecho fundamental, cual es el derecho de libertad de opinión, reconocido en el numeral 12 del artículo 19 de la Carta Magna ${ }^{7}$.

El feminismo como tal lo podemos entender como aquella corriente de pensamiento que propugna la completa igualdad entre hombres y mujeres $^{8}$, como lo fue en su minuto el derecho a sufragar, pero que se extiende también a otros ámbitos, como la igual participación de la mujer en política, la participación en cargos directivos en las empresas, la igualdad de salario, o el rol compartido en la educación y cuidado de los hijos o de los adultos mayores, entre otras.

Según Linda Alcoff, "el feminismo cultural se sustenta en la creencia de que existe una naturaleza o esencia femenina, de la que se apropian las mismas feministas para tratar de revalorizar los atributos femeninos depreciados. Para las feministas culturales, el enemigo de las mujeres no es únicamente el sistema social, las instituciones económicas o una serie de convicciones desfasadas, sino la masculinidad en si misma y, en ciertos casos, lo que es masculino desde un punto de vista biológico... la teoría feminista, la explicación del sexismo y la justificación de las reivindicaciones feministas encuentran una base firme y sin ambigüedades en el concepto de la esencia femenina". Esto, en oposición al patriarcado, entendiendo por tal al "sometimiento y colonización de esta esencia, que encuentran su origen en la envidia y necesidad de los varones" $"$.

Sin embargo, continúa esta autora identificando el problema del feminismo planteado de esa forma, cual es que haría necesario definir la esencia de la mujer, lo cual será nuevamente un concepto cultural o bien indeterminado, e impidiendo por tanto la defensa del feminismo, provocando una paradoja, pues se

Definición propia extraída a partir de la explicación y análisis que da Carlos Cruz-Coke Ossa en idem., pp. 252-256.

Establece el Art. 19 No15 inciso $1^{\circ}$ de la Constitución: "La Constitución asegura a todas las personas: 15": El derecho de asociarse sin permiso previo".

$5 \quad$ Establece el Art. 1 inciso $3^{\circ}$ de la Constitución: "El Estado reconoce y ampara a los grupos intermedios a través de los cuales se estructura y organiza la sociedad y les garantiza la adecuada autonomía para cumplir sus propios fines especificos".

6 Definición propia extraída a partir de la explicación y análisis que da Carlos Cruz-Coke Ossa en CRUZ-COKE OSSA, Carlos, "Instituciones Politicas y Derecho Constitucional', Ediciones Universidad Finis Terrae, Noviembre de 2009, pp. 257-258.

7 Establece el Art. 19 №12 inciso $1^{\circ}$ de la Constitución: "La Constitución asegura a todas las personas: 12: La libertad de emitir opinión y la de informar, sin censura previa, en cualquier forma y por cualquier medio, sin perjuicio de responder de los delitos y abusos que se cometan en el ejercicio de estas libertades, en conformidad a la ley, la que deberá ser de quorum calificado".

8 Sobre el particular, el Diccionario de la Real Academia de la Lengua Española entiende por feminismo, en su primera acepción, como "principio de igualdad de derechos de la mujer y el hombre"

9 ALCOFF, Linda, "Feminismo Cultural vs Post-Estructuralismo: La Crisis de Identidad de la Teoria Feminista", en Journal of Women in Culture and Sociaty, 1988, Vol. 13, No3, University of Chicago, traducción de Rosario Martín Ruano, p. 2.

10 Idem., p. 4. 
critica el efecto cultural y al mismo tiempo lo central del feminismo queda determinado, también, por la cultura. A partir de ello han surgido otras teorías.

Así, por una parte, Lauretis parte también de la base que el concepto de mujer es también un concepto cultural, pero su ventaja "radica en que nunca pierde de vista que la teoría feminista se debe a un imperativo politico y, por tanto, no ignora en ningún momento que nuestra misión no es solo describir la relación en la que se fundamenta la subjetividad de las mujeres sino también cambiarla"11. Según ella, "la subjetividad no está determinada en exceso por lo biológico ni por una intencionalidad libre y racional, sino, más bien, por la experiencia, que define como un complejo de hábitos resultado de la interacción semiótica del mundo exterior $y$ del mundo interior" ${ }^{12}$, buscando una definición de la experiencia femenina.

Por otro lado, Riley apunta a las necesidades femeninas, aunque en su texto se refiere especialmente a la situación de la maternidad (aunque ello no es obligación o natural de la mujer, sino simplemente necesidades coyunturales), siendo compatible la visión feminista con proyectos políticos, como bien lo explica la misma autora ya citada.

Finalmente, la autora (Alcoff) busca dar un concepto metafísico comenzando por el aporte de Lauretis, es decir, basado en la experiencia femenina -en hábitos, costumbres y discursos-, bajo la premisa de que es mudable, el concepto depende del lugar y momento determinado, como realidad histórica. Al mismo tiempo, en todo caso, destaca la autora que debe ser un punto inicial y directriz para la actividad política.

Bajo la postura de esta autora, "el concepto de posiciones... pone su identidad en relación con un contexto perennemente cambiante, con una situación en la que unos elementos se entrelazan con otros como en una red... si se puede definir a las mujeres a través de su posición en este entramado de relaciones, es posible consolidar para ellas una argumentación feminista que no se base en la queja de que se están truncando sus capacidades innatas, sino en la constatación de que su posición en esa trama carece de poder y movilidad, y precisa un cambio radical' ${ }^{13}$. Así, el concepto partiría de lo externo, pero tiene también a la mujer como protagonista, siendo activa en su propia definición.

Este movimiento se caracteriza por su heterogeneidad, siendo una fuerza social difusa, que abarca tanto movimientos políticos como sociales, culturales y económicos. Por ello, es que se puede analizar tanto desde la perspectiva de grupo de presión como fuerza política, en caso de que se organicen, como asimismo en el marco de la opinión pública, si se mantienen desorganizados.

En el caso de Chile este movimiento ha tenido una influencia y apoyo considerable, lo cual quedó de manifiesto en la marcha del 08 de marzo del 2019 pero, incluso antes de ello, se comienza a discutir en otros espacios las demandas del feminismo, como son las mencionadas mas arriba. Esto ha influido tanto en las universidades como en las empresas, los medios de comunicación y, por cierto, incluso en los partidos políticos. Por citar un ejemplo, en el XXXI Congreso Partidario del Partido Socialista de Chile, este partido se reconoció como un partido feminista ${ }^{14}$.

\footnotetext{
Idem., p. 12.

Idem., p. 13.

Idem., p. 19.

Véase las "Conclusiones del XXXI Congreso Socialista Aniceto Rodríguez", particularmente el punto I.3-d) que señala "Del mismo modo el Partido Socialista de Chile contempla el feminismo socialista como perspectiva de análisis, estrategia y contenido de nuestra acción politica. De este modo, el Partido Socialista se declara feminista y antipatriarcal. El feminismo socialista aspira a la igualdad sustantiva entre hombres y mujeres, en todos los ámbitos de la vida política social, tanto pública como privada...” y el punto II.11 referido a políticas de género: la definición del Partido Socialista como partido feminista.
} 
Una de las demandas del feminismo es la igual protección de la ley frente a la violencia de género, lo cual tiene directa incidencia en las tasas de femicidio, de violencia intrafamiliar, de delitos sexuales, y de acoso sexual. En razón de esto, el Derecho Penal es una legislación que claramente se puede ver influido por estas demandas, pues precisamente la sanción de dichas conductas queda a cargo de esta rama jurídica.

Por otra parte, el Derecho Penal también ha estado influido por esta corriente por las demandas de protección en el ejercicio de los derechos reproductivos de la mujer, y en ese escenario, determinar cómo se regula la interrupción voluntaria del embarazo. En este sentido, las demandas del feminismo también pueden ser observadas desde la mirada de los derechos humanos, y concretamente, los derechos humanos de cuarta y quinta generación.

Ahora bien, pese a que se pueda sostener como hipótesis que esta fuerza política ha influido en el Derecho Penal, dicha influencia tiene un riesgo, cual es que se provoque una asimetría inversa, que por lo demás pudiera afectar la igualdad ante la ley, reconocida en los numerales 2 y 3 inciso $1^{\circ}$ del artículo 19 de la $\mathrm{CPR}^{15}$. Asimismo, otro de los riesgos es que se despenalicen situaciones lesivas para bienes jurídicos que el ordenamiento jurídico considere razonables proteger por vía de la herramienta penal. Finalmente, un tercer riesgo es que se incumpla el principio de lesividad y proporcionalidad como parámetro fijado por un Estado Social y de Derecho y se sancionen conductas que no ponen en peligro o dañan a ningún bien jurídico digno de protección jurídico-penal, o se le sancione con una pena mayor a la que sea efectivamente proporcional.

La idea de este trabajo es precisamente estudiar, primero, si es efectiva la hipótesis de que el feminismo ha influido en el Derecho Penal; segundo, cómo ha ocurrido aquello; y tercero, si esa influencia se ha traducido en concretar el riesgo antes identificado o no, es decir, si ha provocado el nacimiento de nuevas asimetrías a la inversa de lo que ocurría con anterioridad a las reformas, que pudiera implicar la inconstitucionalidad de las diversas modificaciones legales en atención a que dicho riesgo implicaría la afectación de la igualdad en y ante la ley, reconocidas por la CPR, o si por el contrario la influencia del feminismo se ha cuidado de no materializar dicho riesgo. Mismo análisis se hará en relación a si despenaliza situaciones lesivas para bienes jurídicos dignos de protección jurídico-penal y respecto de la proporcionalidad de las penas.

Para ello, se profundizará en analizar ciertas modificaciones legales, como son: 1) La Ley de Interrupción Voluntaria del Embarazo, Ley No21.030; 2) La Ley sobre el Femicidio, Ley No20.480; y 3) La Ley sobre Acoso Sexual en Espacios Públicos, Ley No21.153. Para analizarlas, se estará a la historia legislativa de las diversas leyes, así como a algunos comentarios que se pueden hacer en relación al tenor literal de las mismas.

\section{Ley de interrupción voluntaria del embarazo, No21.030:}

Conviene comenzar este apartado explicando el contexto de esta reforma. Antes de la misma, la legislación penal chilena sancionaba el aborto en todos los casos, incluyendo, producto de la llamada Ley Merino de 1989, al aborto terapéutico, sin perjuicio de la posibilidad de discutir en sede de antijuridicidad y culpabilidad la responsabilidad tanto de la mujer que realizó el aborto, como del médico que lo practicó. Esta sanción estaba establecida en el artículo 119 del Código Sanitario en relación con los artículos 342 y siguientes del Código Penal (CP).

Señala el Art. 19 numerales $2^{\circ}$ y $3^{\circ}$ de la Constitución: "La Constitución asegura a todas las personas: $2^{\circ}$ La igualdad ante la ley. En Chile no hay persona ni grupo privilegiados. En Chile no hay esclavos y el que pise su territorio queda libre, Hombres y mujeres son iguales ante la ley. Ni la ley ni autoridad alguna podrán establecer diferencias arbitrarias. $3^{\circ}$ La igual protección de la ley en el ejercicio de sus derechos". 
Esta postura legislativa resultaba cuestionada no solo por los argumentos del feminismo en torno a los derechos reproductivos, sino que también considerando que la minoría de los Estados, en el Derecho Comparado, sancionaban al aborto en toda hipótesis, como era el caso chileno y algunos pocos Estados más como el Vaticano, entre otros. La mayoría de los Estados adhieren a la Teoría del Plazo o a la Teoría de las Indicaciones, siendo minoritarios los Estados que adhieren a las Teorías Absolutas.

Expliquemos esto con un poco más de detalle. La regulación del aborto tiene su punto de origen en determinar cuándo comienza la vida humana, porque desde ese momento el legislador va a decidir proteger al que está por nacer, aunque no necesariamente sea por vía penal. Ahora bien, desde ese momento se cumpliría al menos uno de los principios limitadores del Ius Puniendi, cual es el principio de lesividad ${ }^{16}$. Punto determinante, por lo tanto, es definir cuando hay ser humano.

$\mathrm{Al}$ respecto, en la tramitación de esta ley, en la Comisión de Constitución de la Cámara de Diputados, el profesor Javier Couso destaca que será determinante para la votación definir cuándo se entiende que comienza la vida humana. Así, señala que "la convicción que diferentes grupos tengan respecto del carácter de persona humana (o no) del nonato sigue jugando un rol decisivo en la posición que adopten acerca de la legitimidad de diferentes hipótesis de término voluntario del embarazo. En este sentido, indicó que para quienes están intimamente convencidos de que no existe diferencia filosóficamente significativa entre el embrión o feto y una persona nacida, los argumentos acerca de los derechos reproductivos o la autonomía de la mujer como una razón para autorizarla a hacerse un aborto rara vez tendrán el peso suficiente como para contrapesar que con ello se está terminando con la vida de lo que consideran una persona humana. Por otra parte, para quienes están persuadidos de que -más allá del innegable valor que desde el punto de vista filosófico y constitucional ostenta el nonato- este no tiene, sin embargo, el estatus de una persona humana (y sujeto de los derechos morales y constitucionales que tal condición otorga), llegarán a conclusiones muy diferentes cuando deban sopesar el derecho a la vida, a la salud, a la dignidad, y a la autonomía reproductiva de la madre embarazada vis-a-vis el valor de la protección de la vida del embrión o feto". En el caso de este proyecto, el profesor privilegia el derecho de la mujer por sobre el nonato. Por tanto, definir este momento es determinante.

Así, se distinguen diversas posibilidades. La primera de las teorías es la Teoría de la Concepción, la cual señala que la vida humana comienza desde la concepción, es decir, desde la unión del espermatozoide masculino con el óvulo femenino, por lo que desde ese momento la legislación debe proteger al que está por nacer. Señala la Doctora Mónica López Barahona que "un material genético puede analizarse y discernir si es o no humano identificando si el ADN posee o no un tipo de secuencias denominadas secuencias Alu. El material genético humano posee secuencias Alu y esto lo hace distinguirse del material genético de otras especies. De modo que en el análisis del material genético de un cigoto humano se obtendrían secuencias Alu y por ello, podemos adjudicar el calificativo de humana a la vida que existe en el cigoto humano" ${ }^{17}$. Más adelante señala que "con la fusión de los dos gametos humanos, un nuevo ser humano comienza su propia existencia o ciclo vital, en el que realizará autónomamente todas las potencialidades de que está intrinsecamente dotado, aunque esto deberá suceder dentro de los limites en que está circunscrito cada ser viviente, en particular la patología y la muerte. El embrión, pues, desde la fusión de los gametos, ya no es un potencial ser humano, sino que es un ser humano real' 18 .

16 Sobre los principios que limitan al Ius Puniendi, véase MIR PUIG, Santiago, "Derecho Penal, Parte General (fundamentos y teoría del delito)", pp. 60-85.

17 LOPEZ BARAHONA, Mónica, "El Estatuto Biológico del Embrión Humano", en TOMÁS GARRIDO, Gloria María, "Manual de Bioética", Editorial Ariel, Barcelona, 2001, p. 206.

18 Idem., p. 213. 
Esta teoría ha sido sustentada principalmente por la Iglesia Católica y es la que funda una de las Teorías Absolutas, la cual señala que, como la vida comienza desde la concepción, desde ese momento debe ser protegida sancionando el aborto penalmente en todos los casos y sin excepción. Esta era la teoría a la que se adhería Chile hasta antes de la Ley No21.030 que comentamos.

Esta teoría ha tenido críticas, como bien lo indica Jesús Ballesteros, en alusión a Haeckel ${ }^{19}$. En primer lugar, se indica que no está garantizada la viabilidad del feto, pues cerca de un $50 \%$ de los óvulos fecundados se pierden en el proceso, además que puede luego dividirse, en caso de engendrar gemelos, lo cual contradice la individualidad humana (aunque es una idea debatible, como lo indica el autor en el texto citado). Además, no se puede hablar ni si quiera de embarazo pues no ha existido aun la anidación del ovulo fecundado en la pared intrauterina. Finalmente, se indica que no se puede hablar aún de ser humano, siendo un momento muy temprano, exigiendo más, como son los signos vitales o las funciones encefálicas.

La segunda teoría es la Teoría de la Anidación, la cual señala que comienza la vida solo desde el momento en que el ovulo fecundado se anida en la pared intrauterina, siendo ese momento preciso el que da comienzo al embarazo y cuando ya se tiene viabilidad, según lo explica Jesús Ballesteros ${ }^{20}$. Por lo tanto, todo método que opere con anterioridad a ello no es abortivo, sino solo anticonceptivo si opera antes de la concepción y contraceptivo si opera después de la concepción pero antes de la anidación, como ocurre con la píldora del día después. Para el aborto se exige, por tanto, del embarazo, que solo ocurre al momento de la anidación.

Es útil mencionar que la Corte Interamericana de Derechos Humanos se adhiere a esta teoría. En efecto, en el caso "Artavia Murillo y Otros con Costa Rica", la Corte, interpretando la expresión "concepción" señala que "la prueba cientifica concuerda en diferenciar dos momentos complementarios y esenciales en el desarrollo embrionario: la fecundación y la implantación. El Tribunal observa que solo al cumplirse el segundo momento se cierra el ciclo que permite entender que existe la concepción... si dicho embrión no se implanta en el cuerpo de la mujer sus posibilidades de desarrollo son nulas" 21 , por lo que "el Tribunal entiende el termino concepción desde el momento en que ocurre la implantación"22.

La tercera teoría es la Teoría de los Signos Vitales o de las Funciones Encefálicas, la cual sostiene que se puede comenzar a hablar de ser humano cuando el embrión desarrolla las funciones encefálicas o comienzan sus signos vitales, momento en el cual pasa a llamarse feto. Uno de los fundamentos de esta teoría radica en la postura utilitarista, pronunciándose sobre la experimentación sobre embriones, la cual señala que "la atribución de la titularidad de derechos solo a los que tienen capacidad sensorial y especialmente sensibilidad para el dolor.. hasta que no se haya producido un desarrollo suficiente de la corteza cerebral, entre las 5-8 semanas de la fertilización" ${ }^{23}$. Esta corriente se sostiene en un razonamiento a contrario censu a partir de la definición de la muerte. En efecto, la muerte natural de la persona se entiende como el cese total e irreversible de las funciones encefálicas ${ }^{24}$, de modo que si ese es el momento que determina la muerte, lógicamente el momento en el que inicia la vida humana sería cuando comienzan las funciones encefálicas. Como consecuencia legislativa, esta teoría adhiere a la Teoría del Plazo, pues señala que hasta antes de ese

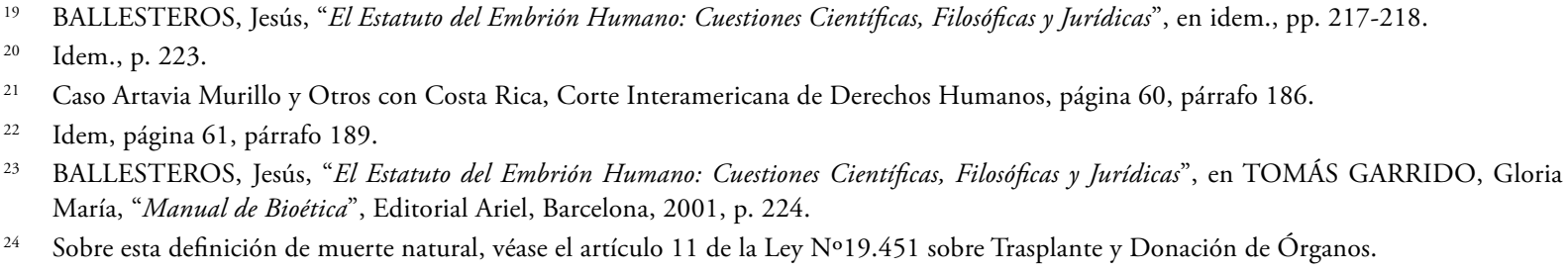

24 Sobre esta definición de muerte natural, véase el artículo 11 de la Ley No19.451 sobre Trasplante y Donación de Órganos. 
momento no debe sancionarse el aborto, sino solo después de ese momento, pues con anterioridad a ello no hay existencia natural de la persona humana y por tanto no hay lesión a bien jurídico alguno.

Ahora bien, sin perjuicio de estas teorías de inicio de la vida, dentro de las teorías de la reacción legislativa, donde ya mencionamos la teoría absoluta de la Iglesia Católica y la Teoría del Plazo derivada de las Teorías de las Funciones Encefálicas y de los Signos Vitales, existen otras dos teorías: Por un lado, la Teoría de las Indicaciones, y por otro lado la Teoría de los Derechos Reproductivos.

Conforme a la Teoría de las Indicaciones, la legislación penal debe sancionar en general al aborto, salvo algunas situaciones consideradas casos límites ${ }^{25}$. Dentro de ellas encontramos a) el aborto terapéutico, que despenaliza a aquel aborto que se practica frente a un riesgo grave a la salud o a la vida de la madre; b) el aborto moral, que despenaliza a aquel aborto que se practica atendiendo a que el embarazo fue producto de una violación; c) el aborto social, que despenaliza a aquel aborto que se practica en razón de la honra de la mujer; d) el aborto por inviabilidad, que despenaliza a aquel aborto que se practica atendiendo a que el feto es inviable de sobrevivir una vez que nazca; e) el aborto engenésico, que despenaliza a aquel aborto que se practica en atención a alguna enfermedad congénita que tenga el feto, que haga complicada su vida al nacer; y f) el aborto maltusiano, que despenaliza a aquel aborto que se practica en atención a políticas sociales de natalidad.

Finalmente, conforme a la Teoría de los Derechos Reproductivos, el aborto en su totalidad debiera estar despenalizado ya que la interrupción voluntaria del embarazo constituye el ejercicio de derechos humanos de la mujer, como son sus derechos reproductivos, por lo que la mujer puede disponer en su totalidad de su propio cuerpo, incluyendo en esto al feto como parte del cuerpo de la mujer.

Como indicamos, antes de esta ley Chile se adhería a la Teoría Absoluta de la Iglesia Católica, sancionando el aborto en todo caso. Más discutible resultaba ser si se adhería a la Teoría de la Concepción o de la Anidación, problema que surgía a raíz de la disposición constitucional que establece que la ley protege la vida del que está por nacer ${ }^{26}$ y la disposición civil que establecía que dicha protección es desde el momento de la concepción, momento en el que comenzaría la existencia natural ${ }^{27}$.

No obstante, este problema se puede resolver señalando que la Constitución no define el momento en que se entiende que se está por nacer, dejándolo al criterio del legislador, y así tampoco obliga a la protección penal, pudiendo protegerse por otras ramas del Derecho. Por su parte, el Código Civil hace esa precisión para la protección de derechos, pero también es claro en señalar que la existencia legal como sujeto de derecho comienza al nacer, con la separación completa del niño con la madre y sobreviviendo un instante al menos ${ }^{28}$. Así, si bien la legislación protege la vida del que está por nacer, no es claro el momento en que comienza ello ni la rama del Derecho que se debe utilizar para su protección, y entendemos al embrión no como un sujeto de derecho sino que como objeto protegido.

A mayor abundamiento, el problema de la teoría a la que se adhiere Chile se puede resolver con dos antecedentes: Por un lado, con el fallo del Tribunal Constitucional sobre la píldora del día después, donde

\footnotetext{
25 Sobre los sistemas de plazo, de indicaciones y casos límites, en particular sobre la legislación española, véase TOMÁS Y GARRIDO, Gloria María, "El Aborto", en TOMÁS GARRIDO, Gloria María, "Manual de Bioética", Editorial Ariel, Barcelona, 2001, pp. 415-434, particularmente para el aborto terapéutico, eugenésico y moral. .

26 Al respecto, véase el artículo 19 No 1 inciso $2^{\circ}$ de la Constitución Política de la República.

27 Sobre la existencia natural, véase los artículos 75 y 76 del Código Civil, que obligan a la protección del que está por nacer y presumen el momento de la concepción a partir del nacimiento.

28 Sobre la existencia legal de la persona, véase el artículo 74 del Código Civil.
} 
primero la declaró inconstitucional y luego constitucional ya que actuaba antes de la anidación, como un contraceptivo de emergencia y por tanto no abortiva; y por otro lado, con la exigencia del tipo penal del aborto del embarazo de la mujer, hecho que ocurre desde la anidación.

Por tanto, antes de esta ley Chile se adhería a la Teoría Absoluta de la Iglesia Católica al sancionar todo tipo de aborto, pero en cuanto a las teorías del inicio de la vida, en un primer momento se adhería a la Teoría de la Concepción y luego a la Teoría de la Anidación, siendo un objeto protegido desde ese momento.

Ahora bien ¿̨uál fue el cambio que se produjo con la Ley de Interrupción Voluntaria del Embarazo, Ley $N^{\circ} 21.030$, que comentamos? Si bien esta ley no modifica la Teoría de la Anidación como momento determinante del inicio de la vida, si modifica la Teoría Absoluta de la Iglesia Católica, ahora adhiriéndose parcialmente a la Teoría de las Indicaciones. En efecto, esta ley viene a despenalizar el aborto en tres situaciones: a) frente a un peligro para la vida de la madre (aborto terapéutico); b) si el embrión es producto de una violación (aborto moral); y c) si el embrión o feto es inviable para sobrevivir al momento de nacer (aborto por inviabilidad). No obstante, quedaron excluidas las otras tres situaciones de esta teoría: a) el aborto eugenésico; b) el aborto social; y c) el aborto maltusiano.

En efecto, el artículo 1 No1 de esta ley modifica al artículo 119 del Código Sanitario señalando que "mediando la voluntad de la mujer, se autoriza la interrupción de su embarazo por un médico cirujano, en los términos regulados en los artículos siguientes, cuando: 1) la mujer se encuentre en riesgo vital, de modo que la interrupción del embarazo evite un peligro para su vida; 2) el embrión of feto padezca una patología congénita adquirida o genética, incompatible con la vida extrauterina independiente, en todo caso de carácter letal; 3) sea resultado de una violación, siempre que no hayan transcurrido más de doce semanas de gestación. Tratándose de una niña menor de 14 años, la interrupción del embarazo podrá realizarse siempre que no hayan transcurrido más de catorce semanas de gestación".

Como bien lo señaló el Profesor José Ignacio Martínez en la Comisión de Constitución de la Cámara de Diputados, en primer trámite constitucional, "el proyecto de ley no es un proyecto de despenalización, sino de indicaciones, y en la tercera causal, combinado con un modelo de plazos, ya que a la mujer se le atribuye la facultad de decidir si continua o no con el embarazo en los casos que se contemplan. El no nacido sería solo un bien jurídico, un objeto de protección, no un sujeto". Es claro entonces que esta ley, manteniéndose en la teoría de la anidación como momento en que inicia la vida o al menos se puede hablar de embarazo, se adhiere parcialmente a la teoría de las indicaciones.

No obstante, tendríamos que aclarar otro punto, cual es si el movimiento feminista se adhiere a la teoría absoluta de los derechos reproductivos de la mujer, a la teoría de las indicaciones, o a la teoría del plazo. Lógicamente, la teoría absoluta de la penalización completa tendría que ser descartada.

En este sentido, sostenemos que el feminismo radical se adherirá a la teoría absoluta de los derechos sexuales y reproductivos de la mujer, defendiendo la despenalización absoluta del aborto por entender que al decidir interrumpir el embarazo no se está afectando derecho ajeno, sino haciendo ejercicio de un derecho propio, cual sería el derecho sexual y reproductivo de la mujer, para decidir sobre su propio cuerpo. Ahora bien, se debe aclarar que habrán otras corrientes al interior del feminismo más moderadas, que adherirían a la teoría del plazo y de las indicaciones, considerando que habría una vida ajena que se ve afectada por el aborto. Es decir, que si existe la posibilidad de lesión a un bien jurídico ajeno, sea posible sancionar esa conducta como delito.

Si bien ningún parlamentario es portavoz del movimiento feminista, si creo necesario observar la historia de la ley para ver si estos argumentos fueron sostenidos durante su tramitación. En este sentido, lo primero 
a destacar es que el mensaje de este proyecto resaltaba como uno de los antecedentes la dignidad de las mujeres y el deber de respeto y protección, señalando que "la normativa vigente sobre interrupción del embarazo, que la prohibe sin excepciones, no responde al trato digno que el Estado de Chile debe otorgar a sus ciudadanas en estas situaciones y sitúa a nuestro país como uno de los cuatro en el mundo que lo criminaliza en todas sus modalidades", y que "los derechos de las mujeres están en el centro de esta propuesta". Luego, en cuanto a los fundamentos del proyecto, el mensaje destaca los compromisos con el Derecho Internacional de los Derechos Humanos, en el sentido de entender que la denegación de la interrupción del embarazo, en todas las circunstancias, puede constituir una vulneración de derechos fundamentales, seńalando que "la prohibición absoluta de interrumpir el embarazo no reconoce que existen circunstancias en las cuales no es exigible a una mujer, por medio de la amenaza de una pena privativa de libertad, que continúe un embarazo", vulnerando el derecho a la vida e integridad física y psíquica de la mujer. A mayor abundamiento, señala que "este proyecto tiene su fundamento principal en el reconocimiento de ciertos hechos, bien definidos, en que debemos reconocer que el Estado no puede castigar a una mujer por no perseverar en un embarazo que no desea y que la sitúa en una posición extrema", permitiendo su decisión.

Luego, en primer trámite constitucional en la Cámara de Diputados, en la Comisión de Constitución, la Ministra del Servicio Nacional de la Mujer, señora Claudia Pascual, señala que en las causales que se discuten ni el Estado ni nadie puede imponer una decisión a la mujer, debiendo avanzar en los derechos humanos de las mujeres, debiendo entregar alternativas tanto a las mujeres que deseen continuar con el embarazo como aquellas que lo deseen interrumpir.

Como se observa, desde el comienzo los derechos sexuales y reproductivos de las mujeres estuvieron como tema en el proyecto, aunque centrado solo en las indicaciones que se debatían, y no así ni en el plazo, ni en la teoría de despenalización absoluta.

Luego, en la misma comisión, el Profesor Agustín Squella ahonda en la libertad de la mujer, señalando que "no se requiere que el derecho resuelva los asuntos morales que cada cual debe resolver por si mismo. Si bien se puede disuadir y argumentar, no es licito imponer una moral, en circunstancias que existen ámbitos legitimos de desacuerdo", de modo que no sería correcta la penalización absoluta del aborto, aun en estos tres casos.

A mayor abundamiento sobre esta ponderación de derechos, la profesora Lidia Casas destaca que la mera declaración de protección a la vida del que está por nacer que hace la Constitución, no resuelve el conflicto con el derecho a la vida, la salud, integridad, dignidad y autonomía de la mujer, pues en toda deliberación se ponderan derechos y valores en juego. Así, el derecho a la vida, la integridad y la dignidad de la mujer, deben ser considerados por el legislador y el Estado. Por el contrario, penalizar todo tipo de aborto resultaría en una vulneración a la igual dignidad de las mujeres. En estas circunstancias limites, el Estado debería apoyar la decisión de la mujer como agente moral autónomo.

Enseguida, Alejandra Zúñiga sostiene que la penalización del aborto en todas las circunstancias despoja a la mujer de sus derechos constitucionales a la vida e integridad física y psicológica, en especial cuando, luego de una violación, se les reduce a cosas o instrumentos de procreación, vulnerando el imperativo categórico de Kant. A mayor abundamiento, interpreta el caso Artavia Murillo y otros con Costa Rica, ya mencionado, precisamente para destacar que el objeto de protección del Art. 4.1 de la Convención Americana ha de ser la mujer embarazada, así como la idea de que la vida desde la concepción hasta el nacimiento puede ser limitada si se enfrenta a otros derechos, como es la autonomía de la mujer embarazada.

Luego, Verónica Undurraga sostiene que en la penalización absoluta del aborto hay una violación a la prohibición en exceso, ya que se vulneran los derechos de la mujer, como son el derecho a la vida, integridad 
física y psicológica, privacidad, libertad de consciencia y religiosa, igualdad y no discriminación, salud y no ser sometida a tratos crueles, inhumanos o degradantes. De este modo, la decisión de la mujer debiera estar amparada por la Constitución.

Por otro lado, el profesor Carlos Peńa destaca que lo central es si estas tres hipótesis pueden implicar la obligación a la mujer de soportar esta carga, existiendo bienes en conflicto. Con mayor profundidad, el profesor Jaime Couso sostiene que el acento en la autonomía de la mujer pone de manifiesto si resulta legitimo cargar a la mujer con esta obligación, y a raíz de ese argumento, el Derecho Comparado ha adherido a la teoría del plazo. Esta autonomía, prosigue, la tienen también las mujeres menores de edad, quienes ya tienen libertad sexual. Luego, respondiendo a las preguntas de los parlamentarios, el profesor aclara que la legislación no da el mismo trato al no nato frente al sujeto ya nacido, de modo que la autonomía de la mujer es el mejor argumento, de ahí que él esté de acuerdo con la teoría del plazo.

Finalmente, el profesor Juan Pablo Mañalich, estando a favor de la teoría del plazo más que de las indicaciones, estima al proyecto de ley como conservador, precisamente por ello, pero igualmente es necesario aprobarlo por los derechos humanos de las mujeres.

Como se observa, es claro que los derechos sexuales y reproductivos de la mujer siempre estuvieron como parte de los argumentos en debate, aunque no en la postura radical de la despenalización absoluta del aborto ni de la teoría del plazo, sino solamente desde la perspectiva de la teoría de las indicaciones.

Luego de este primer trámite reglamentario el proyecto pasa a Discusión en Sala, donde se observa en diversas intervenciones de los Diputados la defensa de la voluntad de la mujer, como fueron las intervenciones de los Diputados Castro, Girardi, Cariola o Gutiérrez, entre otros.

Por mencionar una intervención como ejemplo, este ultimo Diputado sostuvo que "la mujer no es un sujeto interdicto, sino un ser humano con pleno derecho a ejercer su más plena libertad, según le indiquen su conciencia, su autonomia y su dignidad moral. Nada justifica poner en riesgo la vida y la libertad de la madre para responder a caprichos filosóficos y religiosos fundamentalistas... el proyecto no obliga a abortar, sino que genera las condiciones para que las mujeres tomen una elección segura respecto de su cuerpo y de su vida cuando esté en peligro o ha sido ultrajada".

A mayor abundamiento, la Diputada Vallejo señaló que "han pasado 27 años desde 1989, casi tres décadas en las que los derechos a la vida, a la integridad psíquica y física de cientos de miles de mujeres chilenas han sido vulnerados por el Estado de Chile. Honestamente, penalizar a una mujer por interrumpir su embarazo en caso de que peligre su vida, es obligarla a elegir entre cometer un delito o morir. Penalizar a una mujer cuando aborta en caso de que el feto no tenga viabilidad, es castigarla dos veces, como si no fuese suficiente castigo vivir esa tragedia... Penar el aborto en caso de violación es amenazar con cárcel a la victima de un delito repugnante... Estoy absolutamente convencida que penalizar el aborto viola los derechos humanos de las mujeres que viven en Chile; pero también estoy convencida de que con la aprobación de este proyecto estaremos corrigiendo la arbitrariedad y el abuso que hoy nos condenan injustamente. El Estado de Chile transgrede a diario los derechos a la vida y a la integridad física y psíquica de las mujeres, asi como su derecho a la salud, a la libertad y a la autodeterminación, solo por una imposición religiosa y por una obligación ideológica establecida durante la dictadura".

Más adelante otros Diputados continúan enfatizando los derechos de las mujeres, principalmente el de decidir, como se observa en las intervenciones de los Diputados Fernández o Cicardini, entre otros. 
En fin, la discusión en sala de la Cámara de Diputados, en primer trámite constitucional, dieron cuenta de algunos Diputados a favor de los argumentos del feminismo en torno a la libertad de la mujer, así como a su salud e integridad física y psíquica, otros en contra, y una larga discusión relativa a los detalles del proyecto, respecto de cada una de las causales y otros temas, como la objeción de consciencia o el acompañamiento, entre otros. Es destacable, en todo caso, que existió desde el origen la premisa de los derechos sexuales y reproductivos vs la penalización y protección del feto, aunque la discusión se centró más bien en las indicaciones.

Luego, en segundo trámite constitucional, en el Senado, durante primer trámite reglamentario en la Comisión de Salud, la Ministra de la Mujer y Equidad de Género, señora Claudia Pascual, reiteró lo sostenido en la Cámara, en el sentido "que la normativa propuesta se basa en el respeto a la decisión de la mujer que se encuentre en cualquiera de las tres causales antes mencionadas, sea que decida continuar con el embarazo o interrumpirlo".

Luego, en la Discusión en General más parlamentarios, esta vez Senadores, se pronunciaron a favor de la libertad de las mujeres, tal y como se desprende de las intervenciones de los Senadores Rossi o Girardi. De hecho, el Senador Girardi justifica su voto señalando que "la liberalización de la mujer implica rescatar su sexualidad, pues el elemento central se relaciona con sus derechos sexuales y reproductivos... será imprescindible sancionar también la reforma constitucional que consagra los derechos sexuales y reproductivos de la mujer, para que pueda ejercer los derechos que se le conceden atendida su calidad de persona”.

Luego, en Discusión en Sala, otros Senadores reiteraron el punto sobre la libertad de la mujer, como se observa en las intervenciones de los Senadores Harboe o Letelier, quienes incluso sostuvieron que la legislación actual sería inconstitucional por este motivo, es decir, por la falta de proporcionalidad y vulneración de los derechos fundamentales de las mujeres.

En fin, la discusión, como se observa, se centró en los derechos sexuales y reproductivos de la mujer, en la calidad de persona o no del nasciturus, en la legislación penal, constitucional e internacional, y en las indicaciones concretas que estaban en debate. Luego de esto continuó con la discusión en particular en segundo trámite constitucional, y luego el tercer tramite constitucional en comisión mixta, resolviéndose como en definitiva el proyecto fue votado y aprobado.

Ahora bien, como bien se destacó a partir de la historia de la ley, si bien se debatió sobre los derechos sexuales y reproductivos de la mujer, éstos presentan un riesgo, que es que se dañe la vida del nasciturus. La despenalización absoluta podría alterar ese principio, pues existiendo ser humano, tendría que protegerse pese a los derechos reproductivos de la mujer, aunque claro, se podría debatir si dicha protección debe ser por la vía penal. Para evitar la materialización de este riesgo tendría que descartarse la despenalización absoluta y adherirse, en cambio, sea a la teoría del plazo o a la teoría de las indicaciones.

Nuevamente nos detenemos en esta idea: Dependiendo de si hay vida humana y por lo tanto lesión a un bien jurídico en cuestión, podría justificarse el uso de la herramienta penal. Se debe aclarar por tanto que el ordenamiento jurídico no reconoce a quien está por nacer como sujeto, como persona, sino que como objeto protegido considerando que será sujeto. Esto se desprende ya desde la disposición constitucional como la legislación regular. En cuanto a la Constitución, su artículo 1 señala que las personas nacen libres e iguales en dignidad y derechos, coincidiendo con la disposición de Derecho Civil en cuanto a que la existencia legal del sujeto comienza con el nacimiento. 
Asimismo, el artículo $19 \mathrm{~N}^{\circ} 1$ reconoce y asegura a todas las personas el derecho a la vida y a la integridad, pero acto seguido señala que la ley protege la vida del que está por nacer, dando a entender que como no es persona, debe señalarse expresamente que la ley debe proteger a esa etapa pese a no ser sujeto de derecho, pues tampoco se llegó al consenso respectivo, según consta en las Actas de la Comisión Ortúzar. Otro tanto ocurre a nivel legislativo en el Derecho Civil, pues protege la vida del que está por nacer sin entender que ese sea un sujeto, pues de lo contrario no sería necesario regularlo ni suspender sus derechos futuros, pues serían actuales.

Podríamos interpretar que quien está por nacer se refiere al inicio de la existencia natural, esto es, cuando ya es persona (signos vitales o funciones encefálicas), no así desde la concepción o desde la anidación, por lo que se podría proteger legalmente el derecho a la vida de un sujeto desde su existencia natural y no solo desde su existencia legal.

Es relevante limitar la protección legal a ese momento pues la misma Constitución establece normas en cuanto a la regulación penal, exigiendo una cierta proporcionalidad que se determina según el bien jurídico protegido, al igual que el respeto al principio de culpabilidad, de reserva legal y de lesividad. En caso de no haber persona con existencia natural, no hay bien jurídico protegido, y no hay tampoco sujeto pasivo del delito de aborto. De la Constitución y doctrina penal han surgido ciertos elementos que debe contemplar la ley penal, como son el verbo rector, el bien jurídico penalmente protegido, y los sujetos (aunque el sujeto pasivo no es parte del tipo penal), sin perjuicio de otros elementos o algunas variaciones bastante justificadas, de tal modo que si el que está por nacer no es aun persona con existencia natural sino hasta los signos vitales o funciones encefálicas, no puede fundar un tipo penal que sancione a aquel que atente contra su vida o aun contra su integridad, pues faltaría el bien jurídico penalmente protegido.

De esta forma, las indicaciones aprobadas no configuran el riesgo de autorizar una conducta lesiva contra el feto pues aun no concurre existencia natural, momento que ocurre al inicio de las funciones encefálicas o signos vitales. Por tanto, no solo debiese quedar despenalizado el aborto en las indicaciones que se aprobaron, sino que también en el plazo en que el ovulo fecundado no genera aun signos vitales ni funciones encefálicas. El riesgo de provocar un exceso de la influencia feminista en la legislación penal sería solo si se llega a la despenalización absoluta del aborto, pero si se aplica la teoría del plazo y de las indicaciones, no se observa la materialización del riesgo legislativo que examinamos. Mucho menos dicho riesgo se materializa con la modificación actual. Por lo tanto, debemos destacar que el feminismo radical tendería a favorecer la tesis de la despenalización absoluta, pero hay otro feminismo que, entendiendo la existencia natural de la persona, podría adherirse a la teoría del plazo o de las indicaciones. Asumiendo que la Teoría de los Signos Vitales y Funciones Encefálicas es la correcta, bajo un criterio normativo más que filosófico o religioso, pues la muerte es la cesación de las funciones encefálicas y por lo tanto la vida es lo contrario, la despenalización absoluta implicaría la concreción del riesgo, pero no así asumir la teoría del plazo y de las indicaciones.

En este sentido, si bien en la tramitación de esta ley se mencionaron los derechos sexuales y reproductivos de la mujer, se limitó el debate a solo las indicaciones propuestas, no así al plazo ni a la despenalización absoluta. Así, como señaló el profesor Juan Pablo Mañalich citado más arriba, este proyecto es un avance pero aun sigue siendo conservador, debiendo adoptarse, en realidad, la teoría del plazo y de las indicaciones. Si el feminismo sobrepasa dicho limite de plazo e indicaciones, llegando a la despenalización absoluta, se materializaría el riesgo que estamos analizando, pero con el proyecto aprobado, dicho limite no se traspasa, pues queda limitado a las indicaciones propuestas. Por tanto, aun sería posible volver a discutirlo para asumir la teoría del plazo y de las indicaciones, como, por lo demás, lo regulan gran parte de Estados en el Derecho Comparado, sin concretar el riesgo posible. 


\section{Ley sobre el femicidio, No20.480:}

La Ley No20.480 provoca dos cambios relevantes que son necesario analizar. Por un lado, crea la figura del femicidio agregando un nuevo inciso $2^{\circ}$ al artículo 390 que señala que "si la víctima del delito descrito en el inciso precedente es o ha sido la cónyuge o conviviente de su autor, el delito tendrá el nombre de femicidio"; y, por otro lado, agrega un estado de necesidad exculpante como nuevo numeral 11 al artículo 10 del Código Penal, eximiendo de responsabilidad al que "obra para evitar un mal grave para su persona o derecho o los de un tercero, siempre que concurran las circunstancias siguientes: $1^{\circ}$ Actualidad o inminencia del mal que se trata de evitar; $2^{\circ}$ Que no exista otro medio practicable y menos perjudicial para evitarlo; $3^{\circ}$ Que el mal causado no sea sustancialmente superior al que se evita; $4^{\circ}$ Que el sacrificio del bien amenazado por el mal no pueda ser razonablemente exigido al que lo aparta de si o, en su caso, a aquel de quien se lo aparta, siempre que ello estuviese o pudiese estar en conocimiento del que actúa".

¿Por qué estos dos cambios son relevantes? Pues ambos enfrentan la violencia de género, uno sancionando con una mayor pena a quien comete un delito contra la vida de la mujer que es o ha sido su cónyuge o conviviente, y el otro exculpando a quien, tras ańos de sufrir violencia por parte de su pareja, comete un delito contra la persona del agresor. De este modo, se recoge una de las principales demandas del feminismo, cual es el enfrentamiento a la violencia de género.

Ahora bien, el riesgo de dicha demanda es que se genere una asimetría inversa o una exculpante exclusiva de la mujer, es decir, una asimetría inversa en caso que la pena por el homicidio de una mujer sea superior a la pena por el homicidio de un hombre, en circunstancias que ambos bienes jurídicos son el mismo -la vida-y por tanto, su afectación tiene el mismo reproche jurídico penal, lo cual se traduce en la pena que conlleva (otro punto podría debatirse en la presencia de alguna agravante, como pasaré a justificar); y por otro lado, una exculpante exclusiva de la mujer si el estado de necesidad exculpante fuere solo exclusivo de la mujer violentada, no pudiendo invocar esta causal cualquier persona.

Lo central será, entonces, observar si las demandas del feminismo, que provocaron esta reforma legal, materializaron el riesgo de una asimetría inversa o no. Pero comprobemos primero que esta reforma fue producto del feminismo, observando la historia de la ley.

En este sentido, lo primero a destacar es que en la primera moción parlamentaria, se indica como antecedente que "entre los ilícitos que más temor producen en la comunidad, están aquellos que, en el plano familiar, tienen por víctimas a mujeres, particularmente cuando ocurren en el marco de las relaciones de pareja”, y considerando las tasas de este tipo de delitos, se pretende incorporar un nuevo delito como femicidio, pretendiendo suplir un vacío conceptual y de tipificación. Luego, la Diputada señora Muñoz, en el Informe de la Comisión de Familia de la Cámara de Diputados, plantea que "en el plano teórico, la división del parricidio, distinguiendo especificamente como femicidio las conductas contra la mujer, permitirá una mejor comprensión del problema, una adecuada difusión de sus implicancias y constituirá una señal mediática y cultural que apunte decididamente a evitar su ocurrencia".

Por su parte, en la segunda moción parlamentaria, se destaca que el parricidio cometido por la mujer es la respuesta a una dinámica de maltrato intrafamiliar en que la víctima del parricidio era el entonces maltratador, que es muerto por parte de quien era su víctima permanente. Así, la moción señala que "los casos de parricidio... se circunscriben dentro de un contexto de extrema violencia que el padre o quien haga sus veces ha ejercido prácticamente desde el nacimiento del hijo o hija... La desesperación es tal que, en ocasiones, lleva a alguno de los hijos a intentar suicidarse e incluso a la madre a idear la muerte del marido... En definitiva, la realidad antes descrita produce la consecuencia de dar muerte al agresor y golpeador por parte de la 
mujer que lo hace en defensa tanto de ella como de sus hijos". Se proponía, por tanto, agregar un nuevo inciso al artículo 390 que señalara que no tendrá aplicación el delito en caso que el hechor hubiere sido víctima o actúa en defensa de otra persona que ha sido víctima de sevicias con anterioridad a la ejecución del hecho por parte del occiso. En el Informe de la Comisión de Familia de la Cámara de Diputados se planteó en relación a la reacción jurídica frente a esta situación, que "en la legislación chilena solo constituye eximente cuando se obra violentado por una fuerza irresistible, entendiéndose siempre ésta como una fuerza de tipo fisica. Sin embargo, primeramente la doctrina y después en forma parcial la jurisprudencia, han desarrollado el concepto de fuerza moral irresistible; ésta está referida a que a una persona no se le puede exigir más allá de lo que el común de la gente es capaz de soportar", debiendo operar la eximente en estos casos. "Es por ello que tomando especialmente en consideración lo señalado en la legislación argentina, fundamenta incorporar la eximente de obrar bajo la amenaza de un mal grave e inminente".

Estas dos mociones fueron refundidas en un mismo proyecto, según da cuenta el primer informe de la Comisión de Familia de la Cámara de Diputados. En dicho informe se indica que "ambas iniciativas tienen como base sancionar el asesinato de una mujer, causada por una acción de extrema violencia en razón de su género; la primera iniciativa incorpora la figura del femicida para designar al varón que mate a quien haya sido o sea su mujer, o esté o haya estado ligado a una mujer por cualquier otra relación afectiva, acción a la que le atribuye drásticas consecuencias jurídicas. La segunda de las iniciativas, introduce... una nueva eximente de responsabilidad penal, sustituyendo como tal al miedo insuperable por la amenaza de sufrir un mal grave e inminente".

Durante la tramitación, el profesor Raúl Carnevali contextualiza señalando que "se suele hablar de violencia de genero para referirse a aquellos casos en que la mujer es objeto de maltrato físico o psíquico por parte del hombre, producto de ciertas estructuras sociales, en donde se aprecian desigualdades en el reparto de los roles, en desmedro de la mujer y a favor del hombre, quien es el que impone su hegemonía ideológica y el que determina la forma de resolver los conflictos", y, luego de señalar que la vía penal no es la única forma de reacción posible, indica respecto del proyecto que "el fin de la norma es proteger la vida de determinadas personas que se encuentran vinculadas por particulares relaciones, ya sea que éstas provengan de parentesco, maritales o por situaciones de hecho como la convivencia. Sin embargo, la mayor punición no se fundamenta en una especie de presunción de mayor afectividad que debe existir entre estas personas, sino que la existencia de estos vinculos genera entre los involucrados mayor seguridad en cuanto a la integridad de sus bienes jurídicos", es decir, lo esencial es el vínculo que se tiene que permite confiar el cuidado de los bienes jurídicos en juego, más que la afectividad. En este sentido, el profesor Carnevali se oponía a la inclusión de ex pareja o ex conviviente, pues ya no estaba el fin de la norma ${ }^{29}$. A su turno, y concretamente respecto del femicidio, señala que "considerando que ya existen los tipos penales que recogen los supuestos que se comprenderían en el femicidio, parece apreciarse que esta reforma apunta, de manera especial, a resaltar el impacto social que hechos de esta naturaleza generan. Apreciado asi, aquello no puede valorarse negativamente, pues, es innegable la carga simbólica de ciertas palabras", siendo por tanto una modificación semántica. No obstante, luego aclara que la tendencia moderna es la de derogar las figuras del parricidio ${ }^{30}$. Finalmente, respecto de la eximente, señala que constituye "un avance... el que se considerara esta situación de la mujer que ha sufrido reiterados malos tratos por parte de la victima como una circunstancia eximente de responsabilidad criminal, ya que contribuia a otorgar un mayor espacio a la interpretación y a la actuación de los tribunales en consideración de estas situaciones de agresión, que muchas veces motivaban los parricidios cometidos por mujeres".

\footnotetext{
29 En el mismo sentido crítico con la inclusión de ex cónyuges y ex convivientes, véase GONZÁLEZ, Diego, "El Delito de Parricidio: Consideraciones críticas sobre sus últimas reformas”, en Revista Política Criminal, Vol. 10, No19, Julio 2015, pp. 192-233.

30 En el mismo sentido en cuanto a que la tendencia moderna es a la derogación del parricidio, véase idem.
} 
Luego, Soledad Rojas, Coordinadora de la Red Chilena contra la Violencia Doméstica y Sexual, señala que "los términos que se usaban hasta ahora para nombrar los hechos de violencia contra las mujeres... no daban cuenta de los sujetos implicados en ellos, encubriendo la direccionalidad de género de estos crímenes, y las relaciones de poder que los posibilitaban, lo que dificultaba su identificación... Por el contrario, prosiguió, caracterizar los asesinatos de mujeres como femicidio, significaria dar cuenta de los actos de violencia ejercidos sobre estas como forma de poder, dominación y/o control'.

Más adelante, la profesora Lidia Casas señala que el proyecto "busca establecer teóricamente la distinción entre el parricidio y el femicidio para asegurar una mejor comprensión de la violencia en contra de las mujeres por parte de sus parejas o ex parejas... poder simbólico del derecho para disuadir estas conductas".

Luego, la Fiscalía resume señalando que lo que el proyecto hace es "reemplazar el Art. 390 del Código Penal, con el objeto de reformular el delito de parricidio, estableciendo en su lugar dos tipos penales con la misma sanción, como eran el parricidio en el inciso primero y el femicidio en el inciso segundo".

Tras ello y una larga tramitación en que se debatieron diversas indicaciones, el proyecto pasó a Comisión de Constitución de la Cámara de Diputados. En ella, y en relación al término "femicidio", la Diputada señora Saa "creía conveniente que las leyes recogieran las terminologias que expresaban conductas que se producian con frecuencia en la sociedad y que la ciudadania identificaba con dichas conductas", pese a que muchos no estimaban necesario incluir esa expresión pues era una expresión doctrinaria más que legal. A mayor abundamiento, la Diputada señora Muñoz "señaló ser la autora de la idea de incorporar la expresión femicidio en la ley porque ésta se construye sobre la base de las complejidades que tiene el ser humano en la vida social y, por lo mismo, muta constantemente. Agregó que en lo que iba corrido del año se registraban 42 asesinatos de mujeres a manos de sus cónyuges o convivientes, y tanto la ciudadanía como los medios de comunicación habian instalado la voz femicidio para describir tales acciones, de manera que al incluirla en la ley, no se hacía otra cosa mas que recoger un sentir social. Creía igualmente que la inclusión de esta expresión crearía mas conciencia acerca del problema y podría ser un factor de cambio futuro". Tras ello se aprobó la idea de incluir la expresión femicidio.

Resumiendo, el Diputado señor Burgos señaló que "no hay un plus de pena, ni una tipificación distinta. Simplemente se trata de una calificación del legislador en el sentido de que cuando el sujeto pasivo del delito es una mujer y ha mediado la convivencia, el matrimonio, los hijos en común, el autor del delito, según lo califiquen los Tribunales de la República, será condenado por femicidio. Por lo tanto, no se crea un tipo penal nuevo... Más que de carácter jurídico, es una cuestión sociológica de lo que ocurre en el pais, lo cual, a mi juicio, debe ser valorada".

Respecto de la importancia del cambio semántico, el Diputado señor Aedo sostiene que "hay un efecto social... favorece la sanción, porque determina con mayor claridad este horrible delito; constituye una señal a la sociedad, en el sentido de tener un efecto en la opinión pública, lo que puede disminuir la frecuencia del delito", mientras que el Diputado señor Leal sostuvo que "El concepto de femicidio también es útil porque nos indica el carácter social y generalizado de la violencia que se basa en la inequidad de genero... contribuye a desarticular los argumentos de que la violencia de genero es un asunto personal o privado, y muestra su carácter profundamente social, politico, resultado de relaciones estructurales de dominación y de privilegios".

Por otro lado, y en Comisión Mixta, el profesor Enrique Cury expresa sobre la eximente en debate que "el propósito o idea que originó la propuesta de la Honorable Cámara de Diputados es el de ampliar el concepto de estado de necesidad exculpante... y propuso, en su reemplazo, introducir una nueva causal $11^{\circ}$ en el citado Art. 10 del Código Penal', del tenor aprobado. Al respecto, la Senadora señora Alvear prefería discutir ese 
punto en un proyecto aparte, ya que "de aprobarse, resultará aplicable a la conducta tanto a hombres como de mujeres, y a todo tipo de delitos, incluyendo, por ejemplo, a los que afectan la propiedado las conductas funcionarias". Esta causal es luego votada y aprobada.

Como se observa, el debate se centró en ambos puntos: Por un lado, en la inclusión del término "femicidio" en la ley e incluyendo a los ex cónyuges y ex convivientes en el delito de parricidio, y por otro lado, en la creación de la eximente de estado de necesidad exculpante amplia, aplicable tanto para hombres y mujeres y en más situaciones que la dinámica de violencia intrafamiliar.

Respecto de lo primero, se tuvo presente por los parlamentarios que en realidad no se creaba un tipo penal nuevo, sino que solo, luego de ampliar la figura del parricidio a los ex cónyuges y ex convivientes, introducía un cambio semántico, incluyendo la voz "femicidio", con la mira de dar una señal simbólica hacia la sociedad. Asimismo, al seguir la misma tipicidad que el delito del parricidio, tiene también la misma penalidad. Como se observa, la modificación implica un cambio semántico, pues lo relevante no será el género de la víctima (criterio que modifica el nombre del delito, parricidio o femicidio, pero en ambos casos tendrá la misma pena) sino que la relación que los liga, cuestión que se muestra como lógico, sin perjuicio de la posibilidad de agravar la responsabilidad penal por la concurrencia de alguna circunstancia agravante, como sería la contemplada en el artículo 12 No21 del Código Penal, esto es -y en lo que nos interesa- cometer el delito motivado por el sexo de la víctima, circunstancia que no se refiere estrictamente al género femenino de la víctima, sino que simplemente que el delito sea motivado por el género, sea masculino o femenino.

Por tanto, se debe destacar que el feminismo influyó correctamente en la nueva calificación jurídica del femicidio con igual trato al parricidio, pues el criterio rector en ambos es la relación que los liga, y asimismo, se debe considerar la existencia de la agravante general establecida en el numeral 21 del artículo 12, que exige la motivación para el delito a partir del género de la víctima. De este modo, se recoge la influencia del feminismo sin provocar la asimetría penal que sería considerar más grave el homicidio a una mujer que el de un hombre, sin perjuicio de la existencia de la agravante de actuar motivado por un desprecio al género de la víctima.

Ahora bien, en un análisis más general, debemos considerar que la doctrina mayoritaria critica la existencia del parricidio/femicidio como tal. Así, Diego González sostiene que "el parricidio sufrió un proceso de derogación masiva durante el siglo pasado. Dentro de los paises europeos que se han desprendido del tipo cuentan Alemania, Holanda, Suiza, Polonia, Finlandia, Grecia, Noruega y Dinamarca. En cuanto a España, el código de 1995 también optó por prescindir de él, y pese a que se barajó la alternativa de utilizar el parentesco como circunstancia agravante, se prefirió asignarle un carácter mixto" ${ }^{31}$.

De esta forma, resultaría más lógico sancionar como homicidio en ambos casos, pero con la agravante de la concurrencia de la relación particular que los liga, de tal modo que las opciones serían:

1. Sancionar como homicidio ambos casos con la agravante de la relación que los liga, y en caso de ser femicidio, con la agravante, además, de la violencia de género si ha sido motivado por esa razón; o

2. Sancionar como parricidio o femicidio según sea el caso, y nuevamente, agravar la conducta en caso de que sea femicidio y el crimen haya sido cometido motivado por el género de la víctima, aunque se podría discutir si ello infringiría el nen bis in ídem por considerar dos veces el mismo elemento

$31 \quad$ Idem., p. 196. 
(aunque como venimos sosteniendo, son criterios diferentes, uno en atención a la relación que los liga y el otro en atención al género).

La tendencia comparada, en todo caso, se acerca a la primera solución, sin perjuicio de que en el caso chileno, el legislador tiende a la segunda opción, como se vio con la tramitación de este proyecto de ley.

Por lo tanto, destacamos como ideas, primero, que el feminismo influyó en la existencia del femicidio, aunque se trata igual que el parricidio porque lo relevante en el caso sería la relación que los liga más que el género de la víctima, sin perjuicio, además, de la agravante del numeral 21; y segundo, que sin perjuicio de lo anterior, la tendencia más razonable implica la derogación tanto del parricidio como del femicidio, para incluir tanto la relación que liga a los sujetos como la motivación de genero para el delito, como circunstancias agravantes, manteniendo la regulación actual del artículo 13 (circunstancia mixta de parentesco) como del numeral 21 del artículo 12 (agravante de motivación por género), de tal modo de impedir asimetrías penales y permitir su aplicación en otros tipos penales, como las lesiones, por ejemplo.

Teniendo presente lo anterior, el legislador debiera reconducir la influencia del feminismo a las agravantes, no incluyendo o ampliando el femicidio o el parricidio, figuras en retirada, sino que regulando mejor las circunstancias particulares de agravación aplicables a casos de homicidios, sean simples o calificados.

Otro punto a considerar es la aplicación de esta norma como criterio de analogía in bonam partem para la exclusión de responsabilidad penal como encubridor en caso de haber relación de familia, conforme al artículo 17 inciso final del CP, como así también, la posibilidad de usar ese criterio más ampliado para la excusa legal absolutoria del artículo 489 del Código, cuestiones a ser revisadas en la jurisprudencia futura, considerando que dicho tipo de analogía estaría permitido (aunque es discutido).

Por otro lado, en relación a la eximente de responsabilidad del estado de necesidad exculpante, no es una reforma menor, porque esta causal fue incluida considerando a aquella mujer que, tras constantes agresiones de su pareja, decide darle muerte, con una conducta activa, situación que se discute en doctrina comparada, siendo posible la existencia de una legítima defensa (como lo quería legislar Francia), una fuerza moral irresistible o miedo insuperable, o más amplio, inexigibilidad de otra conducta (como sería el caso del estado de necesidad exculpante), o la existencia de una atenuante de obcecación (aunque es de difícil ocurrencia pues puede que el homicidio no sea uno de tipo pasional). Como la doctrina ha precisado, esos casos no siempre quedarán amparados por una legítima defensa, pues ella implica una reacción a un ataque, que puede que no esté ocurriendo en el instante de la comisión del hecho, de tal modo que el estado de necesidad exculpante es más amplio, pues incluye también la conducta activa y no solo la defensiva. Asimismo, usualmente puede haber un exceso en la legitima defensa, situación que no excluiría de responsabilidad penal sino que solo atenuaría la existente. Si además de ello, se descarta la atenuante de la obcecación por no ser un delito pasional, queda entonces circunscrito a la inexigibilidad de otra conducta ${ }^{32}$ y no a una causal de justificación ni a la atenuante en comento.

Ahora bien, hay que aclarar que la causal explicita, pese a su motivación feminista, es más amplia, pues su tenor literal no se refiere a la mujer, sino que admite la aplicación de esa causal a cualquier persona

\footnotetext{
En un sentido similar, sosteniendo que la causal es de exculpación y no binaria incluyendo la justificación, véase CASTILLO, Juan Oablo, "El Estado de Necesidad del Artículo $10 N^{\circ} 11$ del Código Penal Chileno: ¿Una norma bifronte? Elementos para una respuesta negativa”, en Revista Política Criminal, Vol. 11, No22, Diciembre de 2016, pp. 340-367.
} 
y en cualquier supuesto que cumpla con las exigencias abi expresadas, de modo que la inclusión de esta causal no provocó una asimetría penal que hubiera ocurrido si solo se hubiera establecido para la mujer, siendo un acierto.

Por lo tanto, se debe destacar que el feminismo efectivamente influyó en la creación de esta ley, pero que el riesgo de la asimetría penal en la valoración del bien jurídico protegido por el delito, y en la eventual exclusividad de la eximente, no se concretaron, siendo bien reconducido por el legislador frente a un riesgo que si se hubiera materializado hubiera implicado, probablemente, la inconstitucionalidad de la ley.

No obstante, lo lógico para el legislador es tender a eliminar las figuras calificadas del parricidio y del femicidio e incluir esos elementos como agravantes, siguiendo también la tendencia comparada, sea como la circunstancia mixta del parentesco contenida en el artículo 13, o sea la agravante de motivación de género contenida en el artículo 12 No21, que en cualquier caso, no solo exige que la víctima sea de determinado género, sino que éste sea la motivación del delito.

Ahora bien, sin perjuicio de lo anterior, la inclusión de estas figuras puede influir positivamente en la jurisprudencia, mediante analogía in bonam partem, para ser incluidos en las normas sobre encubrimiento y excusa legal absolutoria, tema que se podría discutir en la práctica judicial diaria y ser investigado en otro momento.

Excurso: breve comentario al proyecto de ley que modifica el femicidio, boletín No11.970-34, "Ley Gabriela":

Cabe hacer un breve comentario a un Proyecto de Ley actualmente en trámite que busca modificar la figura del femicidio, conocida como Ley Gabriela. En este proyecto, y a la fecha de redacción de este artículo, se tiene aprobada en general por la Comisión Especial de la Mujer e Igualdad de Género las siguientes modificaciones:

1) Suprime el inciso segundo del artículo 390 que contiene el femicidio reemplazándolo por un nuevo artículo 390 bis que establece: "Será castigado como autor de femicidio, con la pena de presidio mayor en su grado máximo a presidio perpetuo, el que mate a una mujer por razón de su género. Siempre se tendrá por concurrente la razón de genero cuando el femicidio fuere perpetrado en cualquiera de las circunstancias señaladas en los numerales 1, 2, 3, 4, 5, 6, 7, 9, 11, 12, 16, 18 o 21 del artículo 12".

2) En segundo lugar, agrega un nuevo artículo 390 ter que establece: "Será castigado como autor de femicidio agravado, con la pena de presidio mayor en su grado máximo a presidio perpetuo calificado, el que mate a una mujer concurriendo alguna de las circunstancias siguientes:

a) Haber sido la víctima cónyuge o conviviente, o haber tenido una relación de pareja con el autor, habiendo existido o no convivencia;

b) Estar la víctima en estado de embarazo;

c) Ser la víctima menor de edad o mayor de 60 años;

d) Tener la víctima relación de parentesco consanguineo hasta el cuarto grado colateral con el autor;

e) Haberse cometido el hecho en presencia de descendientes menores de edad de la victima". 
3) En tercer lugar, agrega un artículo 393 bis que establece: "Tratándose del femicidio o femicidio agravado, no podrán considerarse las atenuantes previstas en las circunstancias 3, 4 y 5 del artículo 11. Tampoco podrá atenuarse la pena en virtud de la circunstancia $\sigma^{\circ}$ del articulo 11 cuando existan indicios suficientes de que, con anterioridad del femicidio, el autor incurrió en conductas que pueden estimarse como ejercicio reiterado de violencia física o psíquica contra la víctima, sobre otras mujeres, o sobre los descendientes menores de edad de una mujer. Tratándose del delito de femicidio se deberá considerar especialmente la aplicación de las agravantes 1, 2, 4, 6, 7, 9, 18 y 21 del artículo 12".

Sobre este proyecto es del caso señalar que está recogiendo el femicidio con vínculo y el femicidio sin vínculo, distinguiendo entre el calificado y el simple. De esta forma, va en contra de la tendencia moderna que es derogar estas figuras calificadas del homicidio, como ocurre en el Derecho Comparado, según hemos sostenido. Lo ideal sería sancionar solo el homicidio y establecer dos agravantes: el vínculo entre víctima y hechor, y la razón de género que motivó el crimen. De modo similar, se recogen las circunstancias establecidas en los artículos 13 y 12 No21 del CP, según lo hemos indicado.

No obstante esa primera crítica, vale hacer algunos comentarios al respecto. En primer lugar, en relación al femicidio simple, materializa efectivamente el riesgo que hemos identificado anteriormente, pues hace más grave el homicidio de una mujer que el de un hombre toda vez que si, por ejemplo, se mata a un hombre en razón de su genero será considerado homicidio simple con la agravante del artículo 12 No21, mientras que si se mata a la mujer por razón de género, será femicidio sancionado con la pena del parricidio. De esta forma, se genera la asimetría que estamos identificando como riesgo.

Ahora bien, por otro lado, esta figura va a plantear otro problema, cual es probatorio, en el sentido de tener que acreditar la concurrencia del género como motivo del delito, muy similar a acreditar la circunstancia del artículo 12 No21. En este sentido, es útil tener presente que esta circunstancia agravante tiene escasa aplicación en la jurisprudencia, como queda de manifiesto en el Código Penal sistematizado con jurisprudencia escrito por Jean Pierre Matus ${ }^{33}$. En este mismo contexto, el proyecto de ley indicaría que la concurrencia de algunas circunstancias agravantes harían entender la motivación del género para la comisión del delito, cuestión que vulnera la prohibición de presunción de responsabilidad penal y además, las circunstancias no guardan relación alguna con la consecuencia que se asigna. Así por ejemplo, recoge como base para la presunción las circunstancias de alevosía, precio, recompensa o promesa, medios que ocasionen grandes estragos, ensańamiento, astucia, fraude o disfraz, abuso de superioridad de fuerza, abuso de confianza, ignominia, auxilio con gente armada, ejecutarlo de noche o en despoblado, reincidencia, ofensa a la autoridad, o motivación por el género. De todas estas circunstancias, la única que se vincula con la motivación del género es la contemplada en el numeral 21, mientras que las demás no guardan ninguna relación con la consecuencia de estimar que el delito fue por razón del género, de modo que no solo es una presunción de derecho de responsabilidad penal prohibida por el ordenamiento jurídico, sino que además está alejado de la realidad. Por su parte, en el único caso que se vincula (artículo 12 No21) no podría considerarse la misma circunstancia dos veces, por infracción al principio de única persecución.

En segundo lugar, sobre el femicidio agravado, la primera crítica es que conlleva una pena superior al parricidio, provocando una diferencia injustificada (podrían recogerse estas apreciaciones en la concurrencia de circunstancias agravantes, no como calificantes del femicidio), pero aun más, en concreto, hay circunstancias también criticables. La primera de ellas se refiere al vínculo afectivo, cuestión ya criticable pues lo esencial no es ello, sino la vida en común que hace desproteger los bienes

33 Al respecto, véase MATUS ACUÑA, Jean Pierre, "Código Penal Sistematizado con Jurisprudencia", Tercera Edición, Editorial Thompson Reuters, 2017. 
jurídicos en juego, justificándose el delito para cónyuges o convivientes, pero no para ex cónyuges, ex convivientes, o relaciones de pareja ajenas a ambos vínculos. Así, Diego González sostiene que "no es posible recoger un bien jurídico de la sola existencia de una relación pasada, ni desatender únicamente para efectos penales que tales deberes se extinguieron. Esta ficción contradice la conexión lógica que enlaza a los Derechos Civil y Penal. Además, si se entiende que tales deberes de respeto, ayuda mutua y protección subsisten, incluso después de la disolución del vinculo, también tendría que aceptarse la continuidad de la posición de garante que el matrimonio y el concubinato crean, lo cual no parece razonable" 34 . Esto provoca además diferencias injustificadas, pues en el caso en que una ex polola comete homicidio en su ex pololo, cometería homicidio simple, mientras que si es a la inversa, femicidio calificado, con una pena mayor incluso que el parricidio. La segunda de las circunstancias (estar embarazada) podría incluirse siempre que se exija que el autor tenga conocimiento de esta circunstancia, aunque nuevamente, sería mejor incluirla como agravante genérica. Mismo comentario se puede hacer en relación a las demás circunstancias que se indican, es decir, ser incluidas como agravantes genéricas.

En tercer y último lugar, sobre las circunstancias modificatorias, no se observa como justo excluir la aplicación de las atenuantes que se indican, mientras que no se comprende a qué se referiría el legislador al señalar que las agravantes que indica serán consideradas especialmente, es decir, si modifican en algo o no su efecto. Por su parte, considerar especialmente la circunstancia del numeral 21 del artículo 12 sería contrario al principio de única persecución, pues la motivación del genero esta calificando el delito al mismo tiempo que lo agrava.

Visto así, creo que si bien mientras la ley ya aprobada no generó el riesgo identificado previamente (asimetría penal), este proyecto actualmente en trámite si lo hace, particularmente en el femicidio simple, pues se sanciona con mayor pena el homicidio de la mujer vs el del hombre en iguales circunstancias, y a su turno, implicará dificultad en su aplicación por la prueba, prescindiendo, claro está, de la presunción de responsabilidad que establece el proyecto aprobado. Por su parte, materializa también el riesgo en el femicidio calificado, pero más que por las circunstancias, por la pena que tiene, superior al parricidio. Por lo demás, las circunstancias ahí contempladas pueden ser establecidas, con sus precisiones, como agravantes genéricas. Finalmente, el no considerar las atenuantes que indica en estos casos genera también el problema que denunciamos, al mismo tiempo que el considerar especialmente ciertas agravantes, no permite entender a qué se refiere el legislador con especialmente, es decir, si acaso tendrán un efecto diverso o no en la pena. Si así fuere el caso, nuevamente generaría una desigualdad proscrita por el ordenamiento jurídico.

\section{Ley sobre acoso sexual en espacios públicos, No21.153:}

Finalmente, la Ley sobre Acoso Sexual en Espacios Públicos, No21.153, introdujo tres modificaciones al CP: 1) incorpora un nuevo artículo 161 -C por el que se sanciona con presidio menor en su grado mínimo y multa de 05 a 10 UTM al que, en lugares públicos o de libre acceso al público, y por cualquier medio, capte, grabe, filme o fotografíe imágenes, videos o cualquier registro audiovisual, de los genitales u otra parte intima del cuerpo de otra persona con fines de significación sexual y sin su consentimiento. Se aumenta la pena de multa a 10 a 20 UTM al que difunda dichos registros, y, si quien obtiene el registro es la misma persona que la difunde, se aumenta la pena posible a presidio menor en su grado mínimo a

34 GONZÁLEZ, Diego, "El Delito de Parricidio: Consideraciones críticas sobre sus últimas reformas", Revista Política Criminal, Vol. 10 No19, julio 2015, p. 220. 
medio y multa de 20 a 30 UTM; 2) incorpora un nuevo inciso $3^{\circ}$ al artículo 366 en el que sanciona con la pena de presidio menor en su grado mínimo a medio si el abuso consistiere en el empleo de sorpresa u otra maniobra que no suponga el consentimiento de la víctima, siendo mayor de 14 años; y 3) incorpora un nuevo artículo 494 ter para tipificar el acoso sexual respecto de quien realizare, en lugares públicos o de libre acceso a público, y sin mediar el consentimiento de la víctima, un acto de significación sexual capaz de provocar una situación objetivamente intimidatoria, hostil o humillante, que no constituya otra falta o delito más grave, pudiendo ser actos de carácter verbal o gestual, o acercamientos o persecuciones, o actos de exhibicionismo obsceno o de contenido sexual explicito.

En este caso, el riesgo que se presentaba consistía en la forma en que se tipificaran las conductas, considerando las características de fragmentariedad y última ratio del Derecho Penal así como los principios de reserva legal y lesividad, pues la forma en que se tipificara podía ser muy amplia, abarcar aspectos que no debian ser sancionados penalmente y considerar qué bien jurídico era el que se estaba dañando con la conducta que se incrimina, siguiendo un estándar determinado por ser un Estado de Derecho Social y Democrático. Asimismo, otro riesgo estaba en el respeto o no del principio de proporcionalidad, observando las penas que se fijen para cada conducta.

Siguiendo el mismo esquema de los dos apartados anteriores, el objetivo en esta materia es, primero, comprobar que la ley haya sido producto de la influencia del feminismo como fuerza política; y segundo, observar si la legislación aprobada concreta o no el riesgo.

Observemos por tanto la historia de la ley. Esta legislación comenzó con dos mociones que se fusionaron: La primera moción se fundamentaba en que "estos actos atentan directamente contra la honra, dignidad e integridad de las mujeres", sin estar sancionado actualmente bajo ninguna figura residual. La segunda moción se fundamentaba en la necesidad de erradicar las practicas de acoso sexual callejero que experimentan mujeres, hombres, niñas y niños en Chile, adecuando nuestra legislación a lo dispuesto en la Convención sobre Eliminación de todas formas de discriminación contra la Mujer. Asimismo, en esta segunda moción se identificaba como problema la ausencia de una respuesta legislativa adecuada frente al tema, debiendo 1) subsumir los hechos en el actual delito de ofensas al pudor sancionado en el artículo 373 del Código Penal, lo cual "conlleva un error de conceptos al identificar acoso sexual callejero con una ofensa al pudor y las buenas costumbres, olvidando que los bienes juridicos que se pretenden proteger son la libertad e indemnidad sexual'; o 2) subsumirlo en el delito de abuso sexual, sancionado en el artículo 366 del Código Penal, "pero que por sus requisitos deja fuera la mayor parte de las conductas que configuran el acoso sexual callejero".

En la Comisión de Seguridad Ciudadana de la Cámara de Diputados, en primer trámite constitucional y primero reglamentario, María Francisca Valenzuela, presidenta del Observatorio contra el Acoso Callejero, señala que "nuestra actual legislación únicamente da respuesta mediante el artículo 373 del Código Penal... sin embargo, esta legislación no da respuesta a las niñas y mujeres victimas de acoso sexual callejero". A mayor abundamiento, la directora ejecutiva de la misma institución, Bárabara Sepúlveda, indica que "el acoso sexual callejero es una forma de violencia de genero... el grupo de mayor vulnerabilidad son las mujeres. Según el estudio de acoso sexual callejero en Chile, las niñas comienzan a sufrir acoso a los 14 años de edad", lo cual atenta contra los derechos del niño, niña y mujer, como son los reconocidos por la Convención Belem do Pará. Como bienes jurídicos afectados, indica que atenta contra la libertad y seguridad personal, la igual protección ante la ley, la no discriminación, la salud y la indemnidad y libertad sexual. Cabe resaltar que esta iniciativa surge precisamente del Observatorio contra el Acoso Callejero.

Más adelante, la Ministra del Servicio Nacional de la Mujer, señora Claudia Pascual, señala que "el proyecto está orientado principalmente a sancionar la violencia de genero contra las mujeres... este proyecto está en 
la línea de una concepción amplia de la violencia contra las mujeres". Luego, en cuanto al bien jurídico protegido, destaca que "este proyecto también da cuenta de ciertos déficit que tiene nuestra legislación ya que hoy en dia estas conductas estarian subsumidas en las ofensas al pudor y las buenas costumbres, conductas que dicen relación mas con lo colectivo o social más que prevenir y proteger a la victima. Por otra parte, entender estas conductas de violencia incluidas en el delito de abuso sexual, deja fuera a múltiples acciones que no se configuran con dicho delito".

Más adelante, la Directora de la Unidad de Delitos Sexuales de la Fiscalía Nacional, Patricia Muñoz, señala que "la violencia contra la mujer es un fenómeno importante de atender como Estado, dentro de la cual la violencia sexual y otros tipos contemplados en el proyecto de ley son efectivamente graves, aunque lo que es discutible es si es el Derecho Penal el encargado de regular este tipo de materias, teniendo presente su carácter de última ratio, siendo posible que se generen problemas al intentar regular todas las conductas presentes en el referido proyecto". Indica, además, que el actual artículo 373 resguarda otro elemento, como es la moral y las buenas costumbres, debiendo acreditar una merma en tal sentido. Finalmente, propone modificar el artículo 366 para incluir el abuso sexual contra mayores de edad pero con menores requisitos de los actuales, ya que actualmente se intenta subsumir el hecho en la incapacidad de oponer resistencia por parte de la victima, pero la jurisprudencia tiende a rechazar ese argumento.

Luego, la profesora María Elena Santibáńez agrega que "la regulación actual es insuficiente para regular este tipo de materias, coincidiendo que las normas sobre las ofensas al pudor y ultrajes públicos a las buenas costumbres, que en la actualidad constituyen normas que tienden a desaparecer, al ser prácticamente obsoletas ya que toman en consideración cánones morales para establecer la punición de las conductas, en cambio, todo el sistema reformista experimentado a partir del siglo pasado en materia de criminalidad sexual, apunta a proteger un bien jurídico real, que nuestro legislador ha definido como la integridad sexual', exigiendo un daño en ese sentido. Asimismo, el abuso sexual como tal hoy es insuficiente, pues los tribunales no acogen que la sorpresa sea incapacidad para oponer resistencia ${ }^{35}$.

En fin, como se observa en la tramitación en la Cámara de Diputados, en el proyecto efectivamente se tuvo en vista los argumentos del feminismo, comenzando como iniciativa del Observatorio contra el Acoso Callejero para luego ser parte de la argumentación, transversalmente, los derechos de las mujeres.

Continuando con la tramitación del proyecto, terminado su trámite en la Cámara de Diputados, pasó a la Comisión Especial del Senado, encargada de conocer iniciativas y proyectos de ley relacionados con la mujer y la igualdad de género, en donde la profesora Andrea Rojas señaló que el artículo 373 del Código Penal es "un delito en desuso que cautela un bien jurídico difuso, de compleja justificación en un Estado Democrático de Derecho", así como el delito de abuso sexual exige condiciones de la violación o el estupro. Sobre el bien jurídico penalmente protegido en este caso, lo identifica como la intangibilidad de la libertad sexual.

Luego, en Discusión en Sala del Senado, otros Senadores volvieron a destacar la violencia de género como mal a enfrentar, y la protección de los derechos de las mujeres, según se desprende de las intervenciones de los Senadores Muñoz, Latorre y Ordenes. Aun más, los Senadores Latorre y Ordenes mencionan expresamente al movimiento feminista como impulsor de este proyecto.

Sobre el abuso sexual por sorpresa y su atipicidad, véase MATUS ACUÑA, Jean Pierre, “Abusos Sexuales por Sorpresa: ¿Un caso de atipicidad en el Código Penal reformado por la Ley No19.617 de 12 de julio de 1999?", en MATUS ACUÑA, Jean Pierre, "Derecho Penal, Criminología y Política Criminal en el cambio de Siglo", Editorial Jurídica de Chile, 2011, pp. 81-88. 
Luego, en un Segundo Informe de la Comisión Especial, Loretto Ceballos, representante de la Asociación de Abogadas Feministas, ABOFEM; señaló que "el concepto de derechos humanos es evolutivo, de modo que los delitos de genero son una nueva categoría dentro del ordenamiento penal. Por su parte, los delitos sexuales se basan en el género, es decir, ocurren por el significado social del sexo de un hombre o de una mujer en sociedad... se trata de tipos penales de discriminación por sexo", siendo el objeto protegido la integridad sexual.

Tras estas sesiones se acordó incorporar un nuevo artículo 161-C para la captación de imágenes, videos o registro audiovisual, de los genitales u otra parte íntima del cuerpo de otra persona con fines de significación sexual y sin el consentimiento de la víctima, sancionando también al que lo difunde y aumentando la pena si son una misma persona quien capta y difunde. Asimismo, se acordó modificar el artículo 366 para incorporar el abuso por sorpresa y finalmente agregar un artículo 494 ter para efectos de sancionar el acoso sexual callejero. Con esto nos acercamos a lo que finalmente fue aprobado.

Finalmente, y luego del tercer tramite constitucional, se aprueba la nueva ley que, como ya indicamos: 1) incorpora un nuevo artículo 161-C por el que se sanciona con presidio menor en su grado mínimo y multa de 05 a 10 UTM al que, en lugares públicos o de libre acceso al público, y por cualquier medio, capte, grabe, filme o fotografíe imágenes, videos o cualquier registro audiovisual, de los genitales u otra parte intima del cuerpo de otra persona con fines de significación sexual y sin su consentimiento. Se aumenta la pena de multa a 10 a 20 UTM al que difunda dichos registros, y, si quien obtiene el registro es la misma persona que la difunde, se aumenta la pena posible a presidio menor en su grado mínimo a medio y multa de 20 a 30 UTM; 2) incorpora un nuevo inciso $3^{\circ}$ al artículo 366 en el que sanciona con la pena de presidio menor en su grado mínimo a medio si el abuso consistiere en el empleo de sorpresa u otra maniobra que no suponga el consentimiento de la víctima, siendo mayor de 14 años; y 3) incorpora un nuevo artículo 494 ter para tipificar el acoso sexual respecto de quien realizare, en lugares públicos o de libre acceso a público, y sin mediar el consentimiento de la víctima, un acto de significación sexual capaz de provocar una situación objetivamente intimidatoria, hostil o humillante, que no constituya otra falta o delito más grave, pudiendo ser actos de carácter verbal o gestual, o acercamientos o persecuciones, o actos de exhibicionismo obsceno o de contenido sexual explicito.

Observemos por tanto algunos datos relevantes: En primer lugar, según se desprende de las afirmaciones dadas durante la tramitación de esta ley, efectivamente el feminismo influyó en esta legislación, siendo los derechos de las mujeres el centro del debate, aunque sin una claridad suficiente respecto al bien jurídico penalmente protegido, como explicaré. Se incluye como argumento de esta premisa (que el feminismo influyó en esta ley), el que la moción se inicia por el aporte del Observatorio contra el Acoso Callejero y que luego haya sido tramitado por la Comisión Especial sobre Equidad de Género en el Senado, recibiendo comentarios de ciertas instituciones representativas de esta corriente de pensamiento, como es la Asociación de Abogadas Feministas, ABOFEM.

Ahora bien, ya teniendo por acreditada la influencia de esta fuerza política en la creación de la ley, corresponde detenerse en analizar si el riesgo identificado se concreta o no, es decir, observar el bien jurídico penalmente protegido, la forma en la que se regula la conducta, y la proporcionalidad de las penas.

Respecto del bien jurídico penalmente protegido la historia de la ley no aporta mucho a dilucidar el punto, pues en diferentes expresiones se identifican muchos bienes jurídicos en juego. Así, se identifica como bienes jurídicos a la honra y dignidad, la libertad personal y seguridad individual, la igualdad, la salud, y la libertad sexual. Considero que identificar todos estos bienes jurídicos como dañados por el delito es un error, confundiendo el efecto colateral del delito con el efecto inmediato. Más provechosa resulta ser la ubicación normativa en la que cada una de las disposiciones tuvo finalmente. 
Así, el nuevo artículo 161-C se ubica dentro de los crímenes y simples delitos contra derechos garantizados por la Constitución, y concretamente, en el párrafo 5 sobre los delitos contra la vida privada y pública de la persona y su familia. Así, esta primera figura protege la privacidad de la persona. Por otro lado, el nuevo abuso sexual por sorpresa tipificado en un nuevo inciso $3^{\circ}$ del artículo 366 protege directamente la libertad sexual de la víctima, sin perjuicio que el daño que causa, al igual que todos los delitos de índole sexual, se extiende a la salud psíquica de la persona, su honra o su dignidad. Dados estos efectos es que los legisladores, al incluir todos esos bienes jurídicos, confundían el bien jurídico directamente protegido con los que se ven alterados por el daño producido, pero que no se afectan directamente. Finalmente, el nuevo artículo 494 ter que tipifica la falta de acoso sexual callejero, se refiere también a la protección de la libertad e indemnidad sexual en espacios públicos, lo cual afecta también los otros derechos, aunque no directamente.

De esta forma, se deben descartar los otros bienes jurídicos mencionados como protegidos por esta norma y señalar que estas disposiciones, en realidad, protegen la privacidad de la persona, y su libertad sexual, no así el honor y la dignidad (como serian las injurias y calumnias), la salud (como serían las lesiones) o la libertad personal y seguridad individual (como sería el secuestro o la sustracción de menores). Identificar correctamente el bien jurídico penalmente protegido es útil no solo para sistematizar e interpretar el delito, así como para determinar su antijuridicidad material, cumpliendo con el estándar exigido por el principio de lesividad, sino que también para determinar la proporcionalidad de la pena.

Si observamos las penas señaladas, el nuevo artículo 161-C tiene como pena la de presidio menor en su grado mínimo y multa de 05 a 10 UTM para el que capte las imágenes, mientras que el que difunde tiene la misma pena pero con multa de 10 a 20 UTM. Si el que capta es el mismo que el que difunde, la pena llega a presidio menor en su grado mínimo a medio y multa de 20 a 30 UTM. Si comparamos esta pena con el delito del artículo 161-A, que sanciona con la pena de reclusión menor en cualquiera de sus grados y multa de 50 a 500 UTM, ya sea al que capte las imágenes o las difunda, en espacios cerrados, y con la pena de reclusión menor en su grado máximo y multa de 100 a 500 UTM si el que capta es el mismo que el que difunde, observamos que la pena en este delito es mayor que la pena establecida en el nuevo, lo cual se estima como prudente, pues en este caso se afecta la privacidad en espacios cerrados, mientras que en el nuevo delito se afecta en espacios públicos o de libre acceso a público. Esa diferencia del lugar en donde se realiza el delito, puede justificar la diferencia en la penalidad.

Por otro lado, el nuevo inciso $3^{\circ}$ del artículo 366, que sanciona el abuso sexual por sorpresa, tiene como pena la de presidio menor en su grado mínimo a medio, lo cual debe compararse con la pena asignada para el abuso sexual en general. El artículo 366 sanciona al abuso sexual propio con la pena de presidio menor en su grado máximo, mientras que el artículo 366 bis sanciona al abuso sexual impropio con la pena de presidio menor en su grado máximo a presidio mayor en su grado mínimo. Nuevamente, la pena establecida para este caso no resulta ser desproporcionada, en atención a que el orden que baría el Código Penal entre estas tres figuras, en orden de gravedad, sería el abuso sexual impropio como la figura más grave, luego el abuso sexual propio, y finalmente el abuso sexual por sorpresa. Incluso más, aun sería posible aumentar un poco la pena del abuso sexual por sorpresa sin que ello altere la proporcionalidad, siempre y cuando se mantenga bajo el límite inferior de la conducta siguiente más grave, es decir, el abuso sexual propio.

Finalmente, el nuevo artículo 494 ter que tipifica el acoso sexual callejero se sanciona con pena de falta, es decir, de escaso reproche jurídico penal, tampoco viéndose afectado el principio de proporcionalidad. Es más, y esto es llamativo, esta figura tiene una pena menor que el delito de ofensas al pudor y las buenas 
costumbres del artículo 373, en el cual antes se intentaban subsumir los hechos, de modo que aun con la legislación sigue siendo mejor opción acudir al artículo 373.

Por tanto, se puede concluir que la ley efectivamente fue influencia del feminismo, tanto por la institución de la cual emana el proyecto, como por los comentarios vertidos durante la tramitación de la ley, así como por la participación de organizaciones representativas del feminismo, y por la comisión que estuvo a cargo de su tramitación en el Senado. Por su parte, el peligro de tipificar en forma errónea la conducta sancionando hechos que no ameriten sanción penal alguna, no se concreta, pues son figuras que incluso por la comparación de bienes jurídicos involucrados en estas y las figuras relacionadas, podrian aumentar un poco más las penas sin alterar el principio de proporcionalidad, siendo el límite el límite inferior de las figuras inmediatamente superiores, es decir, la afectación a la privacidad del artículo 161-A respecto del 161-C, el abuso sexual propio respecto del abuso sexual por sorpresa, y el delito de ofensas al pudor y las buenas costumbres respecto del acoso sexual callejero. Mientras no se traspasen dichos limites, la pena será proporcional.

\section{Conclusiones:}

Destaquemos brevemente algunas ideas a modo de conclusión:

PRIMERO: El feminismo efectivamente es una fuerza política, que se puede estudiar ya sea como grupo de presión o como opinión pública. Esta corriente ha influido en la legislación penal, como son las tres leyes estudiadas;

SEGUNDO: En todas estas leyes, observando sus historias legislativas, los derechos de las mujeres estuvieron en el centro del debate: en la Ley de Interrupción Voluntaria del Embarazo como los derechos sexuales y reproductivos de las mujeres, así como en su facultad de decidir frente a situaciones extremas; en la Ley del Femicidio como señal política de una nueva nomenclatura del delito, abarcando también ex cónyuges y ex convivientes, así como estableciendo una nueva eximente para la mujer reiteradamente maltratada por su pareja; y en la Ley de Acoso Sexual Callejero, considerando que las mujeres son las principales víctimas de estas situaciones, tanto la captación de imágenes como el abuso sexual por sorpresa y el acoso sexual callejero;

TERCERO: Sin embargo, los riesgos posibles de una influencia del feminismo que afecten la justicia penal no se concretaron, incluso pudiendo avanzar más sin que se concreten. Así, el riesgo de despenalizar todo aborto en circunstancias que desde el inicio de los signos vitales o funciones encefálicas ya hay ser humano, y por tanto ya habría lesión a un bien jurídico digno de protección penal, no se materializó, pues la ley solamente acoge una teoría de las indicaciones, parcialmente referidos al aborto moral, por inviabilidad y terapéutico, y en conjunto con una teoría del plazo para el aborto moral. Lo ideal, en esta materia, sería adherir a la teoría del plazo en primer lugar, y cumplido el plazo, permitir las indicaciones y sancionar los demás abortos así como las lesiones al feto;

CUARTO: El riesgo en la Ley del Femicidio tampoco se concretó, pues el homicidio tanto del hombre como de la mujer sigue teniendo el mismo reproche jurídico penal, siendo lo determinante para que pasen a ser femicidio o parricidio, la relación que los liga (cónyuge, conviviente, ex cónyuge o ex conviviente), y el nombre del delito es lo que cambia según el genero de la víctima, pero no la pena. Sin perjuicio de ello, lo razonable sería derogar tanto el parricidio como el femicidio, manteniendo solo el homicidio con agravantes especiales. Llama la atención, sin embargo, que el proyecto de ley conocido como "Ley 
Gabriela” pudiera concretar el riesgo identificado. A su turno, tampoco se concretó el riesgo de establecer la eximente del estado de necesidad exculpante exclusivamente para la mujer, pudiendo invocarlo también el hombre y en muchas otras situaciones;

QUINTO: Finalmente, el riesgo en la Ley de Acoso Sexual Callejero, en el sentido de sancionar ampliamente una conducta infringiendo el principio de legalidad y lesividad, o de sancionarla en forma desproporcionada, tampoco se concretó. Es más, aun sería posible aumentar un poco la sanción en el caso del abuso sexual por sorpresa hasta el límite inferior del abuso sexual propio y la falta de acoso sexual callejero, hasta el limite inferior del delito de ofensas al pudor y las buenas costumbres, sin que ello implique la afectación del principio de proporcionalidad; y

SEXTO: Por todo lo anterior, es posible sostener que si bien el feminismo como fuerza política ha infuenciado en el Derecho Penal, éste no se ha traducido en asimetrías inversas o afectaciones al principio de lesividad, legalidad o proporcionalidad, sino que ha contribuido en la igualdad efectiva de derechos entre hombres y mujeres, aportando señales políticas claras en torno a visibilizar y erradicar la violencia de género, pero sin que con ello se generen defectos en la armonía del Código Penal.

\section{Bibliografía}

ALCOFF, Linda, "Feminismo Cultural vs Post-Estructuralismo: La Crisis de Identidad de la Teoría Feminista", en Journal of Women in Culture and Sociaty, 1988, Vol. 13, No3, University of Chicago, traducción de Rosario Martín Ruano

BALLESTEROS, Jesús, “El Estatuto del Embrión Humano: Cuestiones Cientificas, Filosóficas y Jurídicas”, en TOMÁS GARRIDO, Gloria María, "Manual de Bioética”, Editorial Ariel, Barcelona, 2001.

CASTILlO, Juan Pablo, “El Estado de Necesidad del Artículo 10 No11 del Código Penal Chileno: ¿Una norma bifronte? Elementos para una respuesta negativa", en Revista Política Criminal, Vol. 11, No22, Diciembre de 2016, pp. 340-367.

CRUZ-COKE OSSA, Carlos, “Instituciones Politicas y Derecho Constitucional', Ediciones Universidad Finis Terrae, Noviembre de 2009.

GONZÁlEZ, Diego, "El Delito de Parricidio: Consideraciones críticas sobre sus últimas reformas", en Revista Política Criminal, Vol. 10, No19, Julio 2015, pp. 192-233.

LOPEZ BARAHONA, Mónica, “El Estatuto Biológico del Embrión Humano”, en TOMÁS GARRIDO, Gloria María, "Manual de Bioética”, Editorial Ariel, Barcelona, 2001.

MATUS ACUÑA, Jean Pierre, “Abusos Sexuales por Sorpresa: ¿Un caso de atipicidad en el Código Penal reformado por la Ley No19.617 de 12 de julio de 1999?”, en MATUS ACUÑA, Jean Pierre, “Derecho Penal, Criminología y Politica Criminal en el cambio de Siglo”, Editorial Jurídica de Chile, 2011, pp. 81-88.

MATUS ACUÑA, Jean Pierre, “Código Penal Sistematizado con Jurisprudencia”, Tercera Edición, Editorial Thompson Reuters, 2017.

MIR PUIG, Santiago, "Derecho Penal, Parte General (fundamentos y teoría del delito)", pp. 60-85.

TOMÁS Y GARRIDO, Gloria María, “El Aborto”, en TOMÁS GARRIDO, Gloria María, “Manual de Bioética”, Editorial Ariel, Barcelona, 2001, pp. 415-434. 